\title{
Checklist and habitat descriptions of edible gastropods from Sarawak, Malaysia
}

\begin{abstract}
Sarawak comprises of vast areas of wetland which is the habitat of huge number of edible gastropods. Among the wetland faunal composition, the edible gastropod is one of the important sources of animal protein for the local communities. This diversity of edible gastropod was studied from seven Divisions of Sarawak namely Kuching, Sibu, Mukah, Bintulu, Miri, Limbang and Lawas. Samples were collected from the wet market and catches from local fishermen. A total of 21 species representing 11 families and 16 genera of edible gastropods were identified from Sarawak. Cerithidea spp. was represented by three species while both Nerita and Pomacea were made up of three and two species each. Others were each represented by one single species. Six edible gastropod species belonged to the freshwater habitat while seven and eight species were recorded from brackish and marine habitats, respectively. Cerithidea and Pomacea showed wide geography amongst the Division and also highly distributed. Edible gastropods have high market value in the state of Sarawak and contribute significantly to the livelihoods of the certain indigenous communities in the state.
\end{abstract}

Keyword: Diversity; Edible gastropod; Habitat; Malaysia; Sarawak; Wetland 